\title{
Effect of Si and Mn on Microstructure and Mechanical Properties of Vacuum Suction Casting Al-4.5Cu Alloy
}

\author{
T. He, ${ }^{\text {a,1 }}$ H. Liu, ${ }^{a}$ X. Shi, ${ }^{\text {b }}$ Y. Huo, ${ }^{a}$ M. Li, ${ }^{\text {a }}$ and T. Pan ${ }^{a}$ \\ ${ }^{a}$ College of Mechanical Engineering, Shanghai University of Engineering Science, Shanghai, China \\ b Fangta Traditional Chinese Medicine Hospital of Songjiang District Shanghai, Shanghai, China \\ ${ }^{1}$ hetao@sues.edu.cn
}

УДК 539.4

\section{Влияние Si и Mn на микроструктуру и механические свойства сплава Al-4,5Cu, полученного литьем методом вакуумного всасывания}

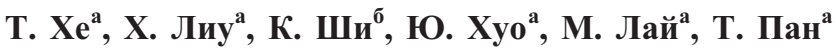 \\ a Машиностроительный колледж, Шанхайский технический университет, Шанхай, Китай \\ ${ }^{\sigma}$ Госпиталь традиционной китайской медицины в Фангте, округ Сунцзян, Шанхай, Китай
}

Высокая эффективность сплавов зависит от микроструктуры, при этом легирующие элементы оказывают значительное влияние на микроструктуру. B матрицу сплава Al-4,5Cи добавляли различное количество легирующих элементов Si u Mn для изучения их влияния на микроструктуру и механические свойства. Комбинированные сплавы отливали методом вакуумного всасывания. Микроструктуру комбинированных сплавов исследовали с помощью растрового электронного микроскопа. Механические свойства определяли при испьтании на универсальной матине и посредством тестера микротвердости. Проанализированы экспериментальные результаты для сплавов с различным содержанием Si и Мn. Установлено, что с увеличением содержания Si и Мп появляется нерегулярная чешуйчатая структура. Твердый раствор с нерегулярной чешуйчатой слоистой структурой получен при содержании Si и Mn 3 вес.\%. Максимальный предел прочности (205,87 МПа) таких сплавов получен при содержании Si и Mn 1 вес.\%, относительное удлинение достигает 34,97\%, микротвердость - 74,6 HV. При содержании Si и Mn 2 вес.\% предел прочности является наименьшим (146,65 МПа), относительное удлинение составляет 24,15\%, микротвердость - 60,2 HV. Относительное удлинение комбинированных сплавов уменьшается с увеличением содержания Si и Mn.

Ключевые слова: сплав $\mathrm{Al}-4,5 \mathrm{Cu}$, микроструктура, $\mathrm{Si}-\mathrm{Mn}$, механические свойства, литье методом вакуумного всасывания.

Introduction. $\mathrm{Al}-4.5 \mathrm{Cu}$ alloy are widely used in many industry fields, such as the aerospace, automotive, aircraft, shipbuilding, construction, chemical industry and national defense, because of its low density, good plasticity, high specific strength, good corrosion resistance, good formability, good electrical conductivity and thermal conductivity, etc. The main strengthening phase of $\mathrm{Al}-\mathrm{Cu}$ alloy is $\mathrm{CuAl}_{2}$, which has strong time-hardening ability and thermal stability, so $\mathrm{Al}-\mathrm{Cu}$ alloy has high temperature performance and high room temperature strength [1].

The casting performance of $\mathrm{Al}-4.5 \mathrm{Cu}$ is poor, because $\mathrm{Al}-\mathrm{Cu}$ casting alloy is a solid solution type alloy. It has many characteristics, such as: a small amount of co-crystal, a wide range of crystallization temperature, dendrite developed resulting in poor fluidity of liquid alloy and the shrinkage than Al-Si alloy to large from liquid to solid. So, it makes 
thermal cracking, shrinkage, segregation and other defects [2, 3]. However, these drawbacks can be improved by adding some alloying elements [4].

Many studies have shown that silicon is the most important single alloying element, which is always used in the aluminum cast alloys to improve the casting properties of Al-Si alloys by increasing the fluidity and reducing solidification shrinkage [5, 6]. Meanwhile, the performance of casting alloy is sensitive to the content of $\mathrm{Mn}$, which always is under the control of 1.0 1.6 wt.\% [7]. In commercial $\mathrm{Al}-\mathrm{Cu}-\mathrm{Si}-\mathrm{Mn}-\mathrm{X}$ (X represents other elements) alloys, $\mathrm{Mg} 2 \mathrm{Si}, \mathrm{Al} 5 \mathrm{FeSi}, \alpha-\mathrm{AlFeMnSi}, \mathrm{AlCuMgSi}$, and $\mathrm{CuAl} 2$ are the second phase, which have influence on the microstructure and mechanical properties [8]. Furthermore, the content of $\mathrm{Mn}$ has the largest effect on the transformation rate of $\mathrm{Al} 5 \mathrm{FeSi}$ to $\alpha$-AlFeMnSi $[9,10]$.

The traditional casting process of Al-based alloys containing Si and $\mathrm{Mn}$ is simple and practicable. However, thermodynamic optimizations have been performed for the $\mathrm{Si}-\mathrm{Mn}$ binary system. As for the $\mathrm{Si}-\mathrm{Mn}$ system, all the available descriptions had certain disadvantages $[11,12]$. Aluminum-copper alloy with the addition of $\mathrm{Cu}$ element has a good mechanical properties and room and high temperature performance. When the $\mathrm{Cu}$ content is 4.0 6.0 wt.\%, the tensile strength of the alloy reaches its maximum, so $\mathrm{Al}-\mathrm{Cu}$ alloy mechanical properties higher [13].

The vacuum suction casting (VSC) is a popular technology process. It is beneficial to improve mechanical properties, because of its fast melting and smooth filling, less casting porosity and slag, and cooling in the copper mold, resulting in the small and uniform grain structure [14]. Therefore, the VSC method in this article is used to prepare $\mathrm{Al}-\mathrm{Cu}-\mathrm{Si}-\mathrm{Mn}$ quaternary alloy.

The aim of this work is to study the effect of alloying elements $\mathrm{Si}$ and $\mathrm{Mn}$ on microstructure and properties of $\mathrm{Al}-4.5 \mathrm{Cu}$ alloy. Firstly, compounded alloy (CA) is prepared using VSC method by changing the contents of alloying elements $\mathrm{Si}$ and $\mathrm{Mn}$. Secondly, microstructure is investigated by SEM. And, mechanical properties of CA are compared using experimental results. Finally, analysis and discussion are carried out to make some conclusions.

\section{Experimental Procedure.}

1.1. Vacuum Suction Casting. CA castings were conducted by high-vacuum arc melting and suction-casting based on $\mathrm{Al}-4.5 \mathrm{Cu}$ alloy. The high-vacuum melting and suction-casting equipment is used in this experiment, shown in Fig. 1. The arc gun is cerium-tungsten rod, which is attached to water-cooled copper electrode. The furnace is filled with high-purity inert gas to avoid oxidation reaction.

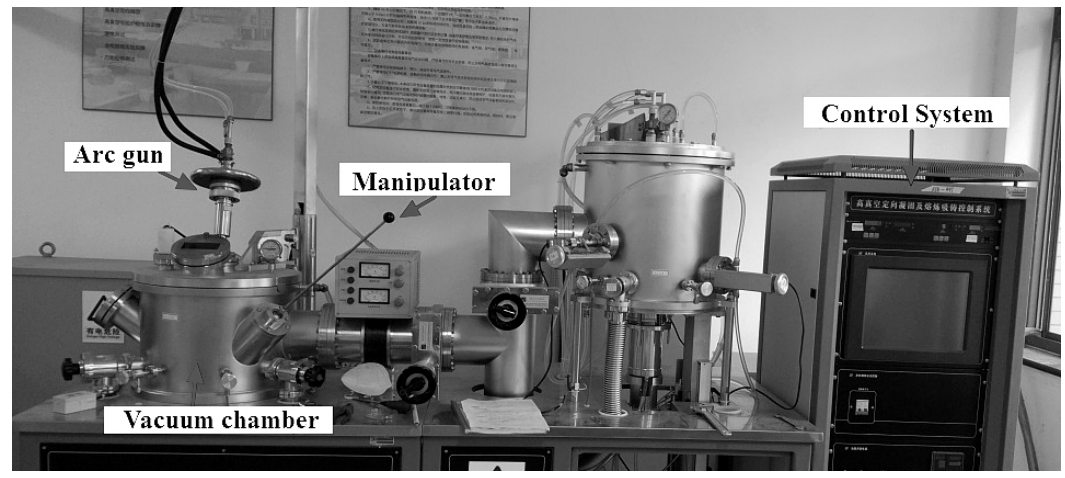

Fig. 1. Experimental equipment of vacuum suction casting.

The procedure of CA castings was divided into four steps. The first step is to weigh $0.9 \mathrm{~g}$ high-purity $\mathrm{Cu}$ and $0.9 \mathrm{~g}$ high-purity $\mathrm{Al}$, and melt in furnace. Secondly, different 
content of Si and Mn were weighed and added into Al-Cu alloy. Detailed percentages of different alloying elements within CA are listed in Table 1. Thirdly, CA with different mass fraction of $\mathrm{Al}-\mathrm{Cu}-\mathrm{Si}-\mathrm{Mn}$ was melted and fully mixed in a high-vacuum arc melting furnace. Finally, CA was sucked into the graphite nozzle with the hole diameter about 2.5 $\mathrm{mm}$ under the protection of argon gas, and casted into copper mold. It was cooled in vacuum to obtain a homogeneous CA bar. The alloy rod is divided into a small cylinder, whose height is about $15 \mathrm{~mm}$, to study the effect of $\mathrm{Si}$ and $\mathrm{Mn}$ on the properties of $\mathrm{Al}-4.5 \mathrm{Cu}$ alloy.

$\mathrm{T}$ a b 1 e 1

Chemical Compositions of Alloys Studied (mass fraction \%)

\begin{tabular}{|c|c|c|c|c|}
\hline Samples & $\mathrm{Cu}$ & $\mathrm{Si}$ & $\mathrm{Mn}$ & $\mathrm{Al}$ \\
\hline $\mathrm{Al}-4.5 \mathrm{Cu}$ & 4.5 & - & - & Bal. \\
$\mathrm{Al}-4.5 \mathrm{Cu}-1 \mathrm{Si}$ & 4.5 & 1.0 & - & Bal. \\
$\mathrm{Al}-4.5 \mathrm{Cu}-1(\mathrm{Si}-\mathrm{Mn})$ & 4.5 & 1.0 & 1.0 & Bal. \\
$\mathrm{Al}-4.5 \mathrm{Cu}-2(\mathrm{Si}-\mathrm{Mn})$ & 4.5 & 2.0 & 2.0 & Bal. \\
$\mathrm{Al}-4.5 \mathrm{Cu}-3(\mathrm{Si}-\mathrm{Mn})$ & 4.5 & 3.0 & 3.0 & Bal. \\
\hline
\end{tabular}

1.2. Microstructure Investigation. The observed specimens were prepared as small square pads by cutting from CA bar of VSC for the sake of microstructure investigation. The thickness of small square pads is $5 \mathrm{~mm}$, and the length of side is $8 \mathrm{~mm}$. The observed specimens were polished to reveal the CA microstructure. The microstructure of CA was observed by Hitachi SU8070 SEM.

1.3. Mechanical Properties Tests. Two tests, microhardness test and tensile test, need to be conducted to evaluate the mechanical properties of CA. Microhardness test is used to measure microhardness of CA. The test specimens are consistent with the observed specimens. And, tensile test is used to measure the stress-strain relationship, i.e., tensile strength.

1.3.1. Microhardness Test. Microhardness of CA is measured by the following test. The test specimens were prepared as cylinders with the length of $12 \mathrm{~mm}$ and diameter of $10 \mathrm{~mm}$ using wire-cut electrical discharge machine. Then the test samples were polished, and put into an ultrasonic cleaner to clean with alcohol, then dried by a blower. The MHVD-1000IS image analysis multifunctional digital microhardness tester was used to measure the microhardness of specimen. Figure 2 shows the distribution of the force on the specimen. Four angular symmetrical heads were used to measure the HV. The maximum load of $200 \mathrm{~N}$ was applied with $3 \mathrm{~s}$. And, seven consecutive points within specimens were selected to measure the microhardness, their average value was recorded as final value of microhardness.

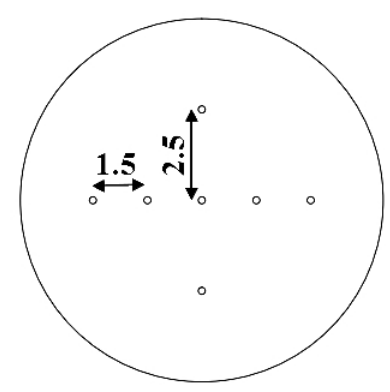

Fig. 2. Distribution of the force on the specimen. 
1.3.2. Tensile Test. Tensile test was conducted on a JVJ-50s microcomputer controlled electronic universal testing machine. Stress-strain curves were measured at a tensile speed of $3 \mathrm{~mm} / \mathrm{min}$ and room temperature during tensile test. Tensile tests were controlled by computer. Strains were measured by extensometer. The tensile test is automatically stretched by the universal drawing instrument. The global strains have been corrected taking into account the machine stiffness. Tensile specimens were stretched with three times to failure under the same tensile condition. And, the average value of the tensile test results was selected as the final experimental data.

Tensile test specimens were prepared as "dog bone" sheet by cutting from CA bars along the longitudinal direction using wire-electrode cutting. The shape and dimension of tensile test specimens is shown in Figs. 3 and 4. As shown in Fig. 3, the original gauge length of the tensile specimen is $13 \mathrm{~mm}$, the width is $3.5 \mathrm{~mm}$, and the thickness is $1.4 \mathrm{~mm}$. And then, the tensile test specimens were polished on the abrasive paper to remove the cutting marks completely to prevent stress concentration and cracks formation during the tensile test.

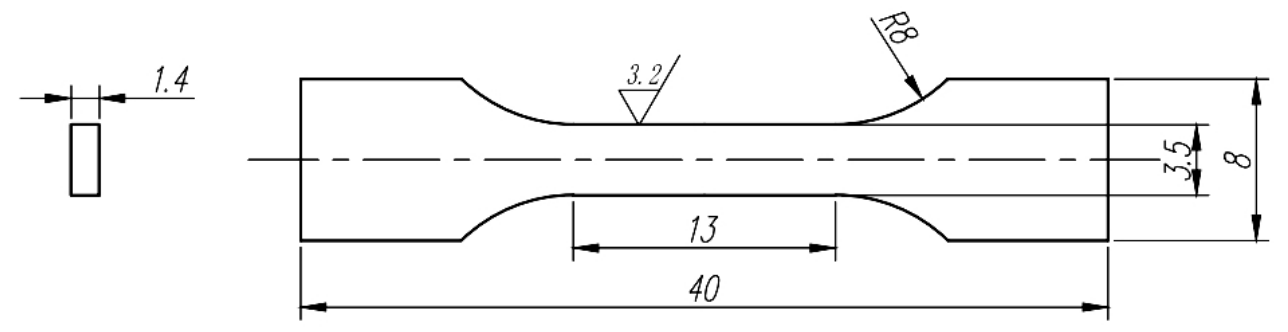

Fig. 3. The shape and dimensions of tensile specimens.

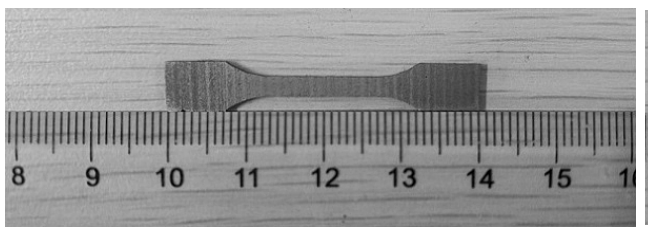

a

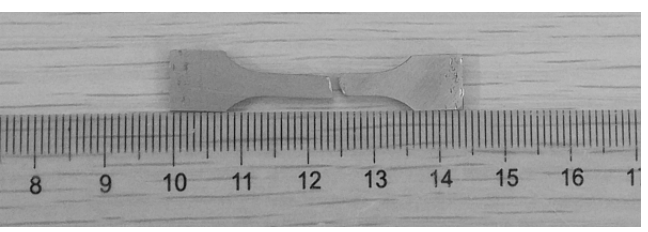

b

Fig. 4. Tensile specimens: (a) before the tensile test, (b) after the tensile test.

\section{Results and Discussion.}

2.1. Effect of Both Si and Mn on Microstructure of $\boldsymbol{C A}$. Figure 5 shows the microstructures of CA with different content of Si and Mn alloy elements. It can be seen from Fig. 5. that $\alpha$-Al phase matrix and solid solution change with the increases of $\mathrm{Si}$ and Mn alloy element. As shown in Fig. 5a, a small amount of Si and Mn elements make the grain structure of CA refinement. The structures of CA are arranged closely and cross-fused to each other. A small amount of small-size solid solution is found in the Fig. 5. Solid solution as the second phase has a certain impact on the performance of CA. That is because that although $\mathrm{Si}$ and $\mathrm{Mn}$ alloy elements can optimize the properties for the castings; $\mathrm{Si}$ and $\mathrm{Mn}$ are also known as an impurity for aluminum-copper alloys.

As shown in Fig. 5b, the structure of CA exhibits irregular sheet lamination and distributs unevenly. The grain boundary voids is too large. The grain size in Fig. 5b is obviously larger than Fig. 5a. There are inclusions and lamellar structures in Fig. 5b. The sheet-like lamellar structure is an impurity ternary phase formed by $\mathrm{Si}$ and $\mathrm{Mn}$, and produces some large-sized inclusions. They are not conducive to improve the performance of CA, and reduce the tensile stress and microhardness. 
Effect of Si and Mn on Microstructure and Mechanical Properties ...
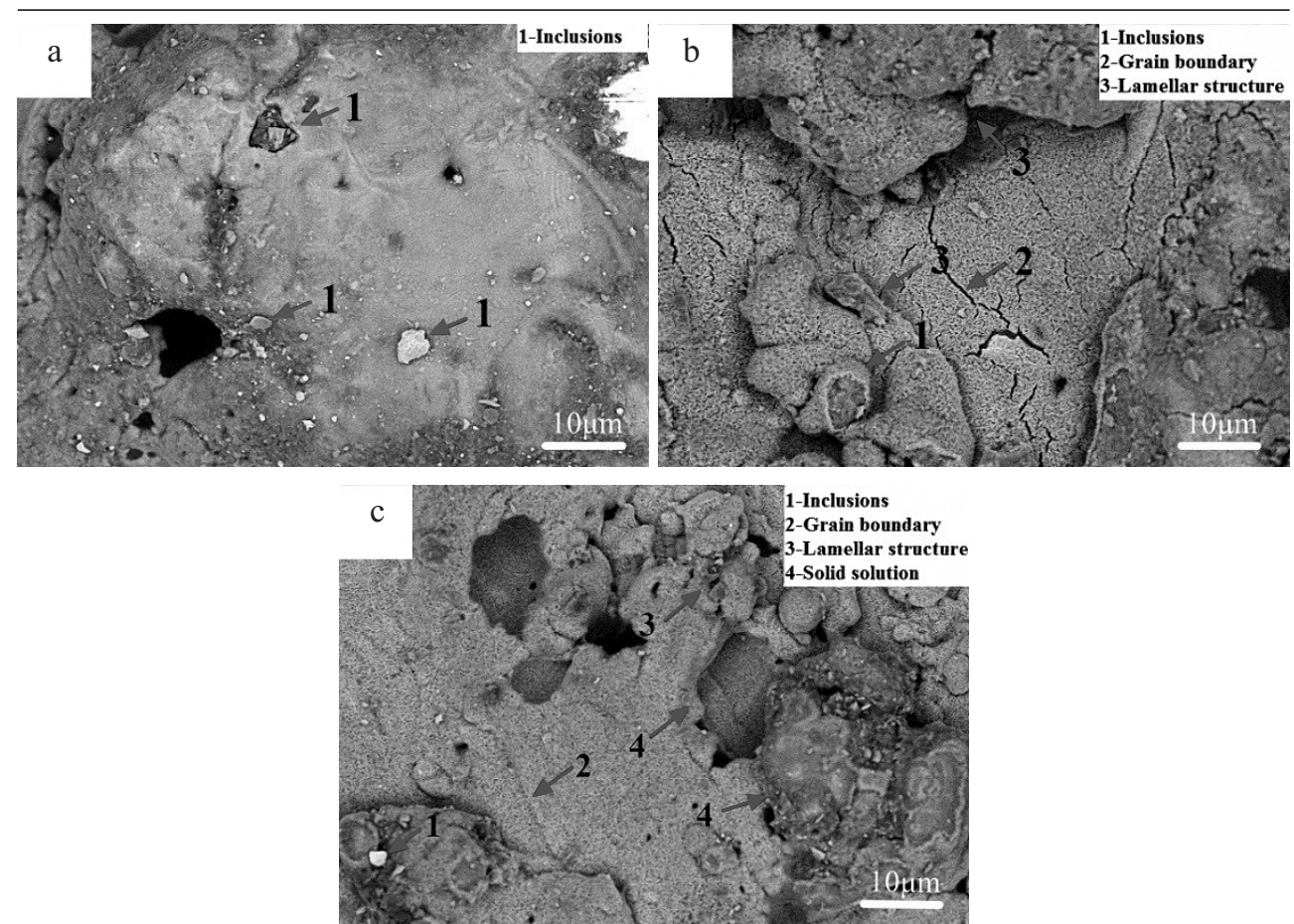

Fig. 5. Microstructures of $\mathrm{Al}-4.5 \mathrm{Cu}-1(\mathrm{Si}-\mathrm{Mn})(\mathrm{a}), \mathrm{Al}-4.5 \mathrm{Cu}-2(\mathrm{Si}-\mathrm{Mn})(\mathrm{b})$, and $\mathrm{Al}-4.5 \mathrm{Cu}-3(\mathrm{Si}-$ Mn) (c) alloys.

As shown in Fig. 5c, with the increase of $\mathrm{Si}$ and $\mathrm{Mn}$ content, $\mathrm{Si}$ and $\mathrm{Mn}$ in the aluminum-copper alloy are supersaturated and partially solid solution, resulting in solid solution strengthening. Part of the emergence of a wide range of compound structure, resulting in a better refinement effect, increased tensile stress. But the large size inclusions in the tissue and the elongated grain boundaries make the tensile stress of high $\mathrm{Si}$ and $\mathrm{Mn}$ content reduced.

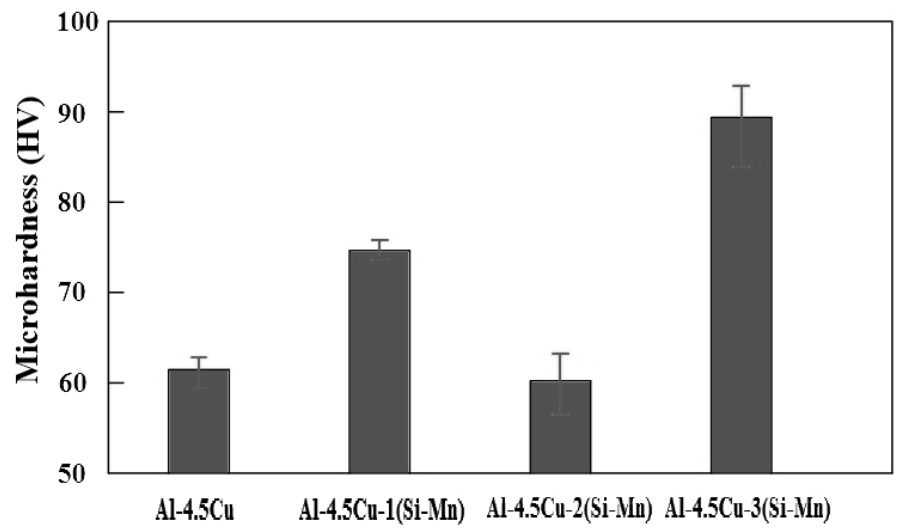

Fig. 6. Effect of both Si and Mn on microhardness of CA.

2.2. Effect of Both Si and Mn on the Microhardness of CA. Figure 6 shows effect of both $\mathrm{Si}$ and $\mathrm{Mn}$ on microhardness of $\mathrm{CA}$. As shown in Fig. 6, the microhardness variation trend with content of $\mathrm{Si}$ and $\mathrm{Mn}$ is the same as the tensile stress for CA. The microhardness 
reaches 74.6 HV when the Si and $\mathrm{Mn}$ are both 1 wt.\%. As shown in Fig. 6, with the increase of $\mathrm{Si}$ and $\mathrm{Mn}$ content from 1 to $2 \mathrm{wt} . \%$, the microhardness of CA decreases from 74.6 to $60.2 \mathrm{HV}$, i.e., decreases about $28.8 \%$. As shown in Fig. 6, when the content of Si and $\mathrm{Mn}$ was $2 \mathrm{wt} . \%$, the microhardness reached the lowest point $60.2 \mathrm{HV}$. Compared with $\mathrm{A} 1-4.5 \mathrm{Cu}-1(\mathrm{Si}-\mathrm{Mn}), \mathrm{Al}-4.5 \mathrm{Cu}-2(\mathrm{Si}-\mathrm{Mn})$ decreases about $18.8 \%$. When content of $\mathrm{Si}$ and $\mathrm{Mn}$ are $3 \mathrm{wt} . \%$, the microhardness reaches $89.4 \mathrm{HV}$, which increases by $48.4 \%$ compared with $\mathrm{Al}-4.5 \mathrm{Cu}-2(\mathrm{Si}-\mathrm{Mn})$.

2.3. Effect of Both Si and Mn on the Tensile Properties of CA. Figure 7 shows effect of both $\mathrm{Si}$ and $\mathrm{Mn}$ on tensile stress and elongation of CA. The maximum force-strain relationship of different content $\mathrm{Si}$ and $\mathrm{Mn}$ alloys are plotted in Fig. 7a. The ultimate tensile stress and elongation of different content $\mathrm{Si}$ and $\mathrm{Mn}$ alloys are plotted in Fig. 7b. Table 2 shows mechanical properties of $\mathrm{CA}$. $\mathrm{Al}-4.5 \mathrm{Cu}-1(\mathrm{Si}-\mathrm{Mn})$ alloy with the addition of $1 \mathrm{wt} . \%$ $\mathrm{Si}$ and $1 \mathrm{wt} . \% \mathrm{Mn}$ has obviously higher ultimate tensile stress than $\mathrm{Al}-4.5 \mathrm{Cu}$ alloy. Its ultimate tensile stress reaches $205.87 \mathrm{MPa}$. It was found that the elongation has been declining with content of $\mathrm{Si}$ and $\mathrm{Mn}$ increased. $\mathrm{Al}-4.5 \mathrm{Cu}$ alloy has obviously higher elongation than others. Its elongation reaches $41.66 \%$.

T a b 1 e 2

Mechanical Properties of CA

\begin{tabular}{||c|c|c|c||}
\hline Samples & Stress $(\mathrm{MPa})$ & Elongation $(\%)$ & Hardness $(\mathrm{HV})$ \\
\hline $\mathrm{Al}-4.5 \mathrm{Cu}$ & 173.182 & 41.657 & $61.5 \pm 1.4$ \\
$\mathrm{Al}-4.5 \mathrm{Cu}-1(\mathrm{Si}-\mathrm{Mn})$ & 205.867 & 34.966 & $74.6 \pm 4.6$ \\
$\mathrm{Al}-4.5 \mathrm{Cu}-2(\mathrm{Si}-\mathrm{Mn})$ & 146.654 & 24.146 & $60.2 \pm 0.2$ \\
$\mathrm{Al}-4.5 \mathrm{Cu}-3(\mathrm{Si}-\mathrm{Mn})$ & 169.970 & 18.963 & $89.4 \pm 9.3$ \\
\hline
\end{tabular}

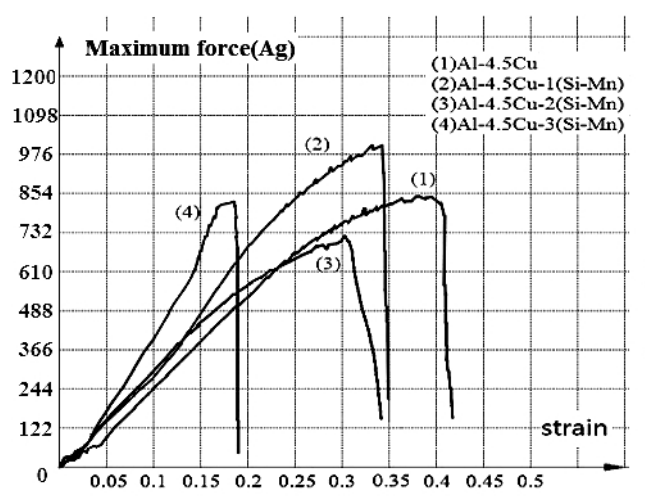

a

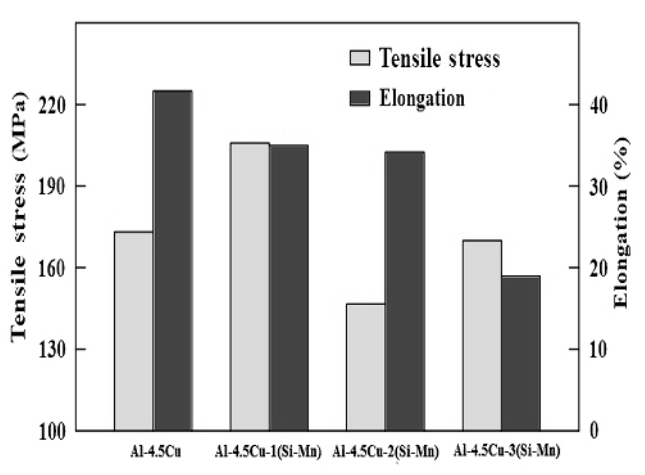

b

Fig. 7. Effect of both $\mathrm{Si}$ and Mn on maximum force-strain curves (a) and ultimate tensile stress and elongation of CA (b).

Comparison of michenical properties is conducted between $\mathrm{A} 1-4.5 \mathrm{Cu}-1(\mathrm{Si}-\mathrm{Mn})$ and $\mathrm{Al}-4.5 \mathrm{Cu}$ in Figs. 6 and 7. It shows that a small amount of Si and Mn elements can enhance the tensile strength and microhardness of $\mathrm{Al}-4.5 \mathrm{Cu}$ alloys. Because a small amount of $\mathrm{Si}$ and $\mathrm{Mn}$ elements have the role of grain refinement. The finer grain structure, the more number of grains are in a certain volume. The effect of grain refinement strengthening is obvious. The tensile stress of $\mathrm{A} 1-4.5 \mathrm{Cu}-1(\mathrm{Si}-\mathrm{Mn})$ increases about $18.5 \%$ and the microhardness increases about 21.5\%. Meanwhile, alloy elongation decreases. The elongation 
decreases about $14.6 \%$. Therefore, adding a small amount of Si and Mn elements will help to improve the mechanical properties of $\mathrm{Al}-4.5 \mathrm{Cu}$ alloys.

The Si and $\mathrm{Mn}$ elements are apt to form the Al10Mn2Si and A16Mn in the aluminum-copper alloy. Wherein, A16Mn is formed in the form of fine flaky needle-like by the peritectic reaction at $983 \mathrm{~K}$ [15]. At room temperature, the main second phase of alloy Al6Mn also can improve the performance.

As shown in Fig. 7, with the increase of $\mathrm{Si}$ and Mn content from 1 to 2 wt.\%, the ultimate tensile stress of CA decreases from 205.87 to $156.65 \mathrm{MPa}$, i.e., decreases about $28.8 \%$, but the elongation keep constant. As shown in Fig. 6, when the content of Si and $\mathrm{Mn}$ is $2 \mathrm{wt} . \%$, the microhardness reaches the lowest point $60.2 \mathrm{HV}$. Compared with $\mathrm{A} 1-4.5 \mathrm{Cu}-1(\mathrm{Si}-\mathrm{Mn}), \mathrm{A} 1-4.5 \mathrm{Cu}-2(\mathrm{Si}-\mathrm{Mn})$ decreases about $18.8 \%$. Research has shown that $\mathrm{Al}$ and $\mathrm{Mn}$ form fine dispersed $\mathrm{Al6Mn}$ particles to promote the formation of subgrain boundaries and retard the grain growth. But $\mathrm{Si}$ and $\mathrm{Mn}$ also can form an impurity ternary phase $\mathrm{T}(\mathrm{A} 112 \mathrm{Mn} 3 \mathrm{Si} 2)$, which weaken the tension strength and microhardness [16].

When content of $\mathrm{Si}$ and $\mathrm{Mn}$ are $3 \mathrm{wt} . \%$, the ultimate tensile stress of CA reaches 169.97 MPa. And, microhardness reaches $89.4 \mathrm{HV}$, which increases by $48.4 \%$ compared with $\mathrm{Al}-4.5 \mathrm{Cu}-2(\mathrm{Si}-\mathrm{Mn})$. With the increase of $\mathrm{Si}$ and $\mathrm{Mn}$ content from 0 to $3 \mathrm{wt} . \%$, $\mathrm{Al}-4.5 \mathrm{Cu}-3(\mathrm{Si}-\mathrm{Mn})$ alloy internal grain refinement. Si and $\mathrm{Mn}$ dissolve supersaturation, resulting in solid solution strengthening. At the same time, irregular sheet-like stacks are reduced. Therefore, its microhardness reaches the highest value. However, the increasing rate of ultimate tensile stress is lower than $\mathrm{Al}-4.5 \mathrm{Cu}-1(\mathrm{Si}-\mathrm{Mn})$.

2.4. Effect of Si or Mn on the Mechanical Properties of CA. The experimental results from Figs. 6 and 7 show that the comprehensive mechanical properties of $\mathrm{Al}-4.5 \mathrm{Cu}-1(\mathrm{Si}-\mathrm{Mn})$ alloy are the best. The addition of $\mathrm{Mn}$ is advantageous for the ductility of the cast $\mathrm{Al}-\mathrm{Cu}$ alloy. However, if $\mathrm{Mn}$ is added above a certain level, the primary coarse $\mathrm{A} 120 \mathrm{Cu} 2 \mathrm{Mn} 3$ phase will form during casting. And, A120Cu2Mn3 does not dissolve into the $\alpha$-Al matrix in the solution, adversely affecting the ductility of the $\mathrm{Al}-4.5 \mathrm{Cu}$ alloy [17]. On the other hand, the $\mathrm{A} 120 \mathrm{Cu} 2 \mathrm{Mn} 3$ dispersion formed in the solution will inevitably consume some of the $\mathrm{Cu}$ element, resulting in lower tensile properties due to reduced precipitation hardening [18]. Therefore, $\mathrm{Al}-4.5 \mathrm{Cu}-1 \mathrm{Mn}$ is not considered in this experiment. Figure 8 shows effect of $\mathrm{Si}$ on tensile stress and elongation of CA. Table 3 shows mechanical properties of CA containing 1 wt.\% Si and without Si. It can be seen from Fig. 8 that a small amount of $\mathrm{Si}$ element is conducive to enhance the tensile properties of CA. $\mathrm{Al}-4.5 \mathrm{Cu}-1 \mathrm{Si}$ alloy with the addition of $1 \mathrm{wt} . \% \mathrm{Si}$ has obviously higher ultimate tensile stress than $\mathrm{Al}-4.5 \mathrm{Cu}$ alloy. Its ultimate tensile stress reaches $194.2 \mathrm{MPa}$. The ultimate tensile stress increases about $12.1 \%$ and the elongation reaches $46.79 \%$. And, two small amounts of $\mathrm{Si}$ and $\mathrm{Mn}$ are also more conducive to enhance the tensile properties of CA. It can be found that the tensile stress of $\mathrm{Al}-4.5 \mathrm{Cu}-1(\mathrm{Si}-\mathrm{Mn})$ is the highest. $\mathrm{Al}-4.5 \mathrm{Cu}-1(\mathrm{Si}-\mathrm{Mn})$ alloy with the addition of $1 \mathrm{wt} . \% \mathrm{Si}$ and $1 \mathrm{wt} . \% \mathrm{Mn}$ has obviously higher ultimate tensile stress than $\mathrm{Al}-4.5 \mathrm{Cu}-1 \mathrm{Si}$ alloy. Its ultimate tensile stress reaches $205.87 \mathrm{MPa}$ and the elongation reaches $34.97 \%$. And, tensile stress of $\mathrm{Al}-4.5 \mathrm{Cu}$ without any $\mathrm{Si}$ and $\mathrm{Mn}$ is the lowest.

$\mathrm{T}$ a b 1 e 3

Mechanical Properties of CA Containing 1 wt.\% Si and without Si

\begin{tabular}{|c|c|c|c||}
\hline Samples & Stress $(\mathrm{MPa})$ & Elongation (\%) & Hardness (HV) \\
\hline $\mathrm{Al}-4.5 \mathrm{Cu}$ & 173.182 & 41.657 & 61.5 \\
$\mathrm{Al}-4.5 \mathrm{Cu}-1 \mathrm{Si}$ & 194.202 & 46.789 & $75.0 \pm 4.9$ \\
$\mathrm{Al}-4.5 \mathrm{Cu}-1(\mathrm{Si}-\mathrm{Mn})$ & 205.867 & 34.966 & 74.6 \\
\hline
\end{tabular}




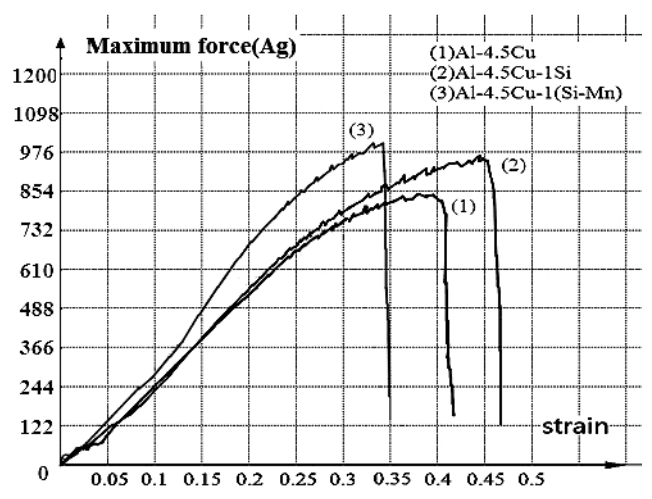

a

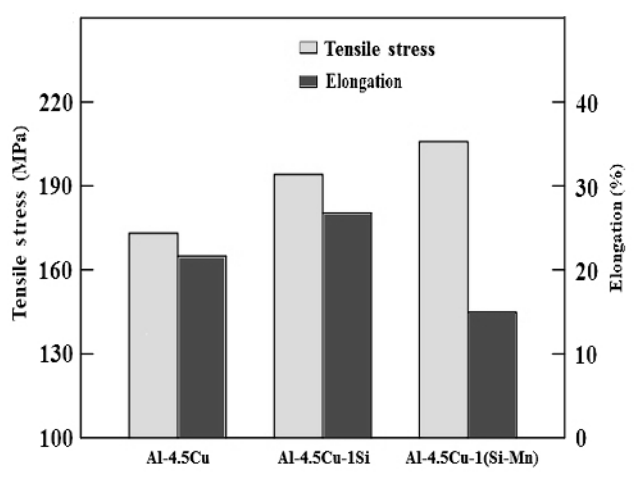

b

Fig. 8. Effect of $\mathrm{Si}$ or $\mathrm{Mn}$ on maximum force-strain curves (a) and ultimate tensile stress and elongation of CA (b).

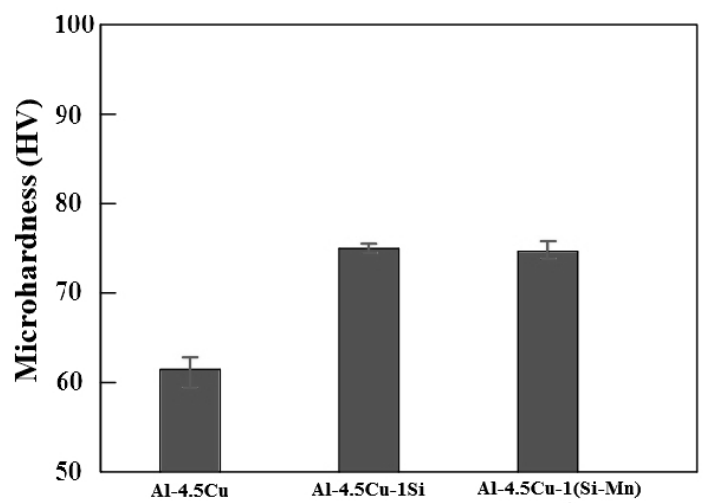

Fig. 9. Effect of $\mathrm{Si}$ or $\mathrm{Mn}$ on the microhardness of CA.

Figure 9 shows effect of $\mathrm{Si}$ or Mn on the microhardness of CA. It can be seen from Fig. 9 that a small amount of $\mathrm{Si}$ or Mn elements can enhance the microhardness of CA. A small amount of Si and Mn make the grain boundary clear, small, and the grain becomes smaller, the size tends to be uniform, which is conducive to enhance the mechanical properties of the alloy. The microhardness reaches $75 \mathrm{HV}$ when the $\mathrm{Si}$ is $1 \mathrm{wt} . \%$ of CA. The microhardness increases about $22.0 \%$. The microhardness reaches $74.6 \mathrm{HV}$ when the $\mathrm{Si}$ and $\mathrm{Mn}$ are both $1 \mathrm{wt} . \%$. Meanwhile, alloy elongation decreases. But the tensile stress increases about $6.0 \%$, while the microhardness decreases about $33.8 \%$. As shown in Fig. 9, the microhardness increasing trend of $\mathrm{CA}$ is the same as the tensile stress increasing trend, shown in Fig. 8.

\section{Conclusions}

1. With the increase of $\mathrm{Si}$ and $\mathrm{Mn}$ content, the irregular lamellar structure of CA appears, and finally the solid solution is coexisted with the irregular lamellar laminated structure.

2. When both $\mathrm{Si}$ and $\mathrm{Mn}$ are not added into $\mathrm{CA}$ during casting, the elongation of $\mathrm{Al}-4.5 \mathrm{Cu}$ is the highest, reaching $41.66 \%$. When both $\mathrm{Si}$ and $\mathrm{Mn}$ are 1 wt.\% in $\mathrm{CA}$, the tensile stress of CA is the highest, reaching 205.87 MPa. When both $\mathrm{Si}$ and $\mathrm{Mn}$ are 2 wt.\% 
in CA, the tensile stress of CA is the lowest, reaching $146.65 \mathrm{MPa}$. The microhardness of $\mathrm{CA}$ is the lowest, reaching $60.2 \mathrm{HV}$. When both $\mathrm{Si}$ and $\mathrm{Mn}$ are $3 \mathrm{wt} . \%$ in $\mathrm{CA}$, the elongation of CA is the lowest, reaching $18.96 \%$. And, the microhardness of CA is the highest, reaching $89.4 \mathrm{HV}$.

3. Adding $1 \mathrm{wt} . \% \mathrm{Si}$ in the $\mathrm{Al}-4.5 \mathrm{Cu}$ alloy, it is beneficial to enhance the mechanical properties of CA. The tensile stress of CA reaches 194.2 MPa. And, its' elongation of CA is the highest, reaching $46.79 \%$. The microhardness of CA is the highest, reaching $75.0 \mathrm{HV}$. Meanwhile, adding $1 \mathrm{wt} . \%$ both $\mathrm{Si}$ and $\mathrm{Mn}$ in the $\mathrm{Al}-4.5 \mathrm{Cu}$ alloy, it is also beneficial to enhance the tensile stress of CA.

Acknowledgments. This project is funded by Research on Key Technologies of Underwater Vehicles for Deep-sea Oil and Gas Fields (Grant No. 16030501200) and 17KY0106 Prediction of Mechanical Properties of Aluminum Alloy Oriented to Solidification Based on Artificial Neural Network (Grant No. E3-0903-17-01006). The Robot Functional Materials Preparation Laboratory in Shanghai University of Engineering Science is also gratefully acknowledged.

\section{Резгме}

Висока ефективність сплавів залежить від мікроструктури, при цьому легуючі елементи значно впливають на мікроструктуру. У матрицю сплава Al-4,5 Cu додавали різну кількість легуючих елементів Si i Mn для вивчення їх впливу на мікроструктуру і механічні властивості. Комбіновані сплави відливали методом вакуумного всомктування. Мікроструктуру комбінованих сплавів досліджували за допомогою растрового електронного мікроскопа. Механічні властивості визначали при випробуваннях на універсальній машині та за допомогою тестера мікротвердості. Проаналізовано експериментальні результати для сплавів із різним вмістом Si i Mn. Установлено, що зі збільшенням вмісту Si i Mn має місце нерегулярна лускоподібна структура. Твердий розчин із нерегулярною лускоподібною шаруватою структурою отримано при вмісті Si i Mn 3 ваг.\%. Максимальну границю міцності (205,87 МПа) таких сплавів отримано при вмісті Si i Mn 1 ваг.\%, відносне подовження сягає 34,97\%, мікротвердість 74,6 HV. При вмісті Si i Mn 2 ваг.\% границя міцності є найменшою (146,65 МПа), відносне подовження сягає 24,15\%, мікротвердість - 60,2 HV. Відносне подовження комбінованих сплавів зменшується зі збільшенням вмісту Si i Mn.

1. S. K. Xie, R. X. Yi, Q. Huang, et al., "Effects of rare earth Ce on fluidity and hot tearing trend of Al4.5Cu alloy," Nonferr. Met., No. 6, 007 (2011).

2. L. A. Dobrzański, R. Maniara, M. Krupiński, and J. H. Sokowski, "Microstructure and mechanical properties of AC AiSi9CuX alloys," J. Achiev. Mater. Manuf. Eng., 24, No. 2, 51-54 (2007).

3. G. Mrówka-Nowotnik, J. Sieniawski, and M. Wierzbińska, "Analysis of intermetallic particles in AiSilMgMn aluminium alloy," J. Achiev. Mater. Manuf. Eng., 20, Nos. 1-2, 155-158 (2007).

4. M. Wierzbińska and J. Sieniawski, "Effect of morphology of eutectic silicon crystals on mechanical properties and cleavage fracture toughness of AlSi5Cul alloy," $J$. Achiev. Mater. Manuf. Eng., 14, Nos. 1-2, 31-36 (2006).

5. S. O. Adeosun, S. A. Balogun, L. O. Osoba, et al., "Effect of $\mathrm{Cu}$ and $\mathrm{Zn}$ addition on the mechanical properties of structural aluminum alloy," J. Modern Manuf. Technol., 3, No. 1, 103-110 (2011).

6. H.-F. Huang, "The influence of pure rare earths $\mathrm{Ce}$ on the castability of $\mathrm{Al}-4.5 \% \mathrm{Cu}$," Mech. Eng., No. 6, 35-36 (2004). 
7. M. Zhao and B. Liu, "Friction and wear behavior of aluminum manganese alloy and its composites," Spec. Cast. Nonferr. Alloy., 31, No. 12, 1148-1150 (2011).

8. J. E. Janse, L. Zhuang, J. Mooi, and P. De Smet, "Evaluation of the effect of $\mathrm{Cu}$ on the paint bake response of preaged AA6xxx," Mater. Sci. Forum, 396-402, No. 2, 607-612 (2002).

9. W. F. Miao and D. E. Laughlin, "Effects of $\mathrm{Cu}$ content and preaging on precipitation characteristics in aluminum alloy 6022," Metall. Mater. Trans. A, 31, No. 2, 361-371 (2000).

10. Y. Wu, J. Xiong, R. Lai, et al., "The microstructure evolution of an Al-Mg-Si$\mathrm{Mn}-\mathrm{Cu}-\mathrm{Ce}$ alloy during homogenization," J. Alloy. Compd., 475, Nos. 1-2, 332-338 (2009).

11. A. Allam, P. Boulet, C. A. Nunes, et al., "Phase transformations in higher manganese silicides," J. Alloy. Compd., 551, 30-36 (2013).

12. A. Berche, E. Ruiz-Théron, J. C. Tedenac, et al., "Thermodynamic description of the Mn-Si system: an experimental and theoretical work," J. Alloy. Compd., 615, 693702 (2014).

13. S. K. Xie, X. Q. Zheng, R. X. Yi, et al., "Analysis on microstructure of AlSi7Cu5 alloy by slope near-liquidus method," Key Eng. Mater., 419-420, 517-520 (2010).

14. B. Aremo and M. O. Adeoye, "A low-cost vacuum casting equipment for aluminium alloys,” Russ. J. Non-Ferr. Met., 51, No. 2, 124-130 (2010).

15. D. T. L. Alexander and A. L. Greer, "Solid-state intermetallic phase tranformations in 3XXX aluminium alloys," Acta Mater., 50, No. 10, 2571-2583 (2002).

16. L. Niu-Can, L. Jun-Qing, Y. Ming-Sheng, "Influence of Re and Mn additions on Fe-containing phase in Al-Si alloys," Foundry Technol., No. 11, 014 (2011).

17. L. F. Mondolfo, "Aluminum alloys: structure and properties," Metal Sci., 35, No. 11, 408 (1976).

18. A. Chen, L. Zhang, G. Wu, et al., "Influences of Mn content on the microstructures and mechanical properties of cast Al-3Li-2Cu-0.2 Zr alloy," J. Alloy. Compd., 715, 421-431 (2017). 